\title{
The Role of Physical Activity
}

and Performance Orientation

on the Scale of Subjective

Preferences to Personal Values

of Romany Pupils

\section{Ondřej Ješina, Tomáš Vyhlídal}

\begin{abstract}
The article focuses on subjective preferences in Romany pupils with an emphasis on physical activity and performance orientation. One of the most important determinants of physical activity in children and youth is their social environment and ethnical background including persons with social disadvantages. However, we find a lack of research on this topic. OBJECTIVES: The aim of the research is to analyze the structure of the scale of subjective preferences to personal values in Romany pupils and their relationship to physical activity and performance orientation. METHODS: To determine social skills indicators, we used the technique of incomplete sentences and three wishes. We created the scale of subjective preferences to personal values. In total 70 respondents of Romany ethnicity participated in the research. They were attending elementary school, and there were 38 boys and 32 girls among them. The sampling was non-random. They were 11.9 years old (11.6 in boys, 12.2 in girls) on average. RESULTS: The respondents in the age group between 9 and 13 years regard the following categories as most important: performance orientation (17.98\%); common activities are on the second position
\end{abstract}


(15.71\%); material focus at things is also noticeable (13.69\%); ideals (11.79\%); however, physical activity also plays an important role in their lives (10.83\%). The subjects put almost no emphasis on categories related to dislike for school $(0.36 \%)$, weather $(0.48 \%)$, hurting of themselves or another person $(0.71 \%)$ and animals $(0.83 \%)$. CONCLUSION: Physical activity has a relatively significant role in the value orientation of Romany pupils (5th position). Focusing on performance is even the most significant preference in both the genders. Moreover, interesting, although not surprising is the finding related to the Romany girls who do not emphasize physical activities (including dancing) as much as it might be expected. Unlike the girls, however, the boys evaluate sport activities as the fourth most important value, right after the common activities.

Key words: adapted physical activity; quality of life; multiculture education; inner motivation.

\section{Introduction}

From the point of view of the Czech law, Romany pupils are included in the same way as pupils with impairment - pupils with special education needs. The principles of education are similar (Jesenský, 1995; Rybová \& Kudláček, 2010; Válková, 1998; Vítková, 2006). Taking into account the aims of the research, especially the social skills of Romany pupils are important in relation to their psychology. According to several authors (Bakalár, 2004; Horňák, 2005; Říčan, 1998; Sekyt, 1998; Ševčíková, 2003; Šotolová, 2001; Žáková, 1976), the psyche of Romany people is in some aspects different from the others. Jánsky (1995) states that the differences of the Romany ethnic group are caused by the distinct ethnographic development, a different way of thinking and problem solving (traditional cooperation with the community), different manners and value orientation, tradition, emotionality, aspiration levels, language variability in distinct social groups etc. Ševčíková (2003) described the archetypes of time and space experience, preference of pleasure, dream interiorizing, social communication, and individualism negation. According to the author, the experience of time and space represents especially the fact that the Romany people limit the perception of time only to the currently experienced situations. They are less likely to consider the future. A great number of the Romany people express the necessity to primarily satisfy their needs as well as univocal preference for strong experience even when risking future loss (Ševčíková, 2003). The material aspect of the culture is not preserved. The Romany people did not pay much attention to it; perhaps because they were getting the material things from the rest of the majority population. Dream interiorizing represents a smaller ability to distinguish one's private wishes and desires from the reality. As a result, the Romany people put their desire over the reality. Also, they are often reluctant to believe something that 
did not go through the process of interiorization (Horváthová, 2002). These people do not have any need of fulfilling personal ambitions by e.g. developing their career at work (Ševčíková, 2003).

Value system or individual preferences are one of the essential prerequisites of human behavior. According to our opinion, it is difficult to make any generalized statements about this phenomenon. Nevertheless, some authors (Bakalář, 2004; Ševčíková, 2003) state the order of the preferences are as follows - independent life, acknowledgement of the family hierarchy and tradition, heritage of the ancestors, love to children, and money as a basic need for survival. Some authors (Horváthová, 2002) believe that living at the expense of the majority, whose approach has been mostly restrictive over the history, gradually became a common and natural phenomenon. The preferences are related to the sense of human life and its fulfillment. "Each community creates its personal value system taking into account its history and social position" (Balvín, 2004). Davidová (In Balvín, 2004) analyzed the value system of the Romany people and created a model of the relationship structure within their community. The author focuses, above all, on the individual, material, social, and spiritual aspects.

Physical activity represents such actions, in which people more or less freely participate, express themselves, learn and verify their knowledge, skills and ideas (Ješina, Kudláček, et al., 2011; Kudláček \& Ješina, 2008). It allows us to work with individuals in a relatively natural environment, where people usually take off their social masks. Therefore, assessments can be done and personalities or preferences influenced in a positive way. Physical activity is considered a necessary part of any strategy and implementation of multicultural education of socially disadvantaged pupils (in our country these are mostly Romany children) (Boyce, 1996; Butt \& Pahnos, 1995; Harrison \& Worthy, 2001; Hodge, 1997; Hutchinson, 1995; Chepyator-Thomson, 1994; Kahan, 2003; King, 1994; McCollum, Civlier, \& Holt, 2004; Sparks, 1994; Sutherland \& Hodge, 2001; Sutliff, 1996; Sutliff \& Perry, 2000; Wessinger, 1994). Block (2007) however pointed out that there is a lack of research of multicultural education, and that there are no sources focusing on multicultural education and differences in connection with adapted physical activity. Regular physical activity is very suitable for maintaining one's health and improving the quality of lives in any age (Freedson, 1991; Trost, Pate, Saunders et al., 1997). To a certain degree, physical activity is a good predictor of health in children and youth (Sallis \& Patrick, 1994; Baranowski, Bouchard, Bar-Or et al., 1994). Sallis, Prochaska and Taylor (2000) stated that one of the most important determinants of activity and inactivity in children and youth in this age group is their ethnical background. These findings confirmed the previous research (Sallis, Patterson, Buono et al., 1988). However, there are a few studies not confirming the importance of ethnicity (Pate, Trost, Felton, et al., 1997). 


\section{Research design}

The aim of the research is to analyze the structure of the scale of subjective preferences to personal values in Romany pupils and their relationship to physical activity and their performance orientation.

Based on this aim we specified the following research questions:

What is the structure of subjective preferences to personal values in the studied Romany pupils?

What are the differences between the subjective preferences to personal values between boys and girls?

What is the position of physical activity and performance orientation within the general subjective preferences of Romany boys and girls?

\subsection{Methods}

To determine social skills indicators we used the technique of "incomplete sentences" according to Válková $(1996,2000)$ that is considered a projective method, and we created the scale of subjective preferences to personal values. the test was translated, transformed from English to Czech, and standardized in 1995 (Válková, 1996). The original technique of "incomplete sentences" was inspired by Fischer et al. (1963 In Válková, 2000) and created by the Special Olympics board in 1995 (Válková, 2000). The method that we used included nine incomplete sentences and three "wishes".

Incomplete Sentences Technique

I would like to

I wish that I.

If only I

I hope that.

I am

I would like most to

It is the best when

People think that I

Sometimes I think about

If I had three magic wishes that would be fulfilled, I would wish: 


\section{Instruction}

Please, read each stem out loud to the client and record their answers verbatim. To avoid bias, and to prevent the client from giving answers that he (she) thinks you want to hear, please do not give your respondent any feedback as they offer their answers. If your respondent says "I don't know", encourage them to think about it for a moment. If they are still stuck, go on to the next one, and then go back to that one at the very end and try the stem again. Start with telling the respondent: "I'm going to read the beginning of a sentence out loud, and I want you to finish it with whatever you think or feel, whatever comes to mind. Any answer that you give is the right one because it is your opinion, your thoughts or feelings. I will write your answers down. Ready? Here is the first one".

When summarizing the content of the utterances, a category analysis was carried out. The responses were classified in 15 categories (see the following text). Such classification made it possible to determine the amount of respondents who scored in the given category (absolutely and proportionally in the total number of respondents in the sample). We could also determine the amount of category units - i. e. the number of the same responses, e.g. in the category "animal", out of the maximum amount of answers - and their percentage in the maximum possible amount of category units (category units = individual responses classified in categories.) The maximum number of category units for each subject was twelve (nine sentences and three wishes). The categories were translated to the Czech language by Válková (1996) and used in another research (Válková, 1998, 2000). According to our findings, the categories are applicable for our focus group but we added the category distaste for school and hurting of oneself or another person. We replaced sport activities by more general physical activities.

\subsection{Description of Categories}

animals: own them, play with them, look after them. detestation oneself or another person: suicidal tendencies, kill or beat somebody common activities: mainly drawing - painting, working (in general and in a specific position), singing, embroidering, gardening, listening to music, activities related to daily routine, care for oneself and entertainment, relaxing, sleeping.

performance orientation: having tendency to achieve something, accomplish, learn something, manage to do something, be successful, not to fail.

things (own them, want them): things of daily need, toys, more expensive things (recorder, car, motorbike, satellite television, playstation, mobile).

home: be at home, partake in activities related to home and siblings, activities typical for close family life (be with the family members), have close friend.

weather: weather, season of the year, time of the day: the weather is nice, it is sunny, spring etc. 
hypercriticism: negative (hostile) evaluation of the person by the environment or the person himself/herself: silly, ugly, fat, dirty, I lie, they don't like me.

indiscrimination: positive or even exaggerated evaluation of one's person: smart, skilful, hardworking, beautiful, fast, good friend.

behavior: I am nice, obedient, naughty, I can behave, think about myself.

physical activities: participating in sport activities including dancing, traveling, going fro trips and walks, preparing for contests, have sport equipment.

ideals: help others so that there is peace, people don't argue, have a good life, satisfaction, unrealistic ideals, be aware of the value of health (of the person and of others). abstract contents: unclassifiable responses: stating one's name, incoherent and repeated utterances, sentences mostly without any context with the initial thought - George, I am, I am pleased, I am here.

I don't know.

RESISTANCE TO SCHOOL: escape from the school, avoid test.

\subsection{Description of the participants}

Determining the ethnicity of the Romany pupils becomes problematic once we focus on the individual as a "subject of study". To establish the criteria determining whether it is a Romany pupil or not we followed the standards of the Ministry of Labor and Social Affairs (Gabal analysis and consulting, 2006, 4). The standards define a Romany as "a person who perceives himself/herself as a Romany although he/she does not have to declare it in all circumstances (e. g. census), and/or who is perceived to be a Romany by a great part of his/her environment based on real or deemed anthropological features, family manners and other indicators".

The respondents were the pupils of basic school with the majority of Romany pupils with social disadvantages. We select the schools on the bases of recommendation by the official Regional Council. The respondents were selected by non-random sampling. We focused on the good cooperation schools. $100 \%$ of addressed pupils were included into research. The teachers of the schools obtain the written agreement by legal representative (most often the parents) at the parents meetings. The respondents were interviewed individually at the presence of a third person (mostly the teacher's assistant). The respondents were given the beginnings of the sentences and they were supposed to react immediately. The examiners recorded all authentic reactions of the subjects including agrammatism, displayed behavior, need of stimulation during the interview etc. The examiners were unknown persons for respondents. They were be instructed by main examiner and they know about official instruction according to original (Válková, 2000). All the subjects successfully managed this form of activity. In total 70 respondents of the Romany ethnicity (see above) participated in the research. They were attending elementary school, and there were 38 boys and 32 girls among 
them. Because of the organization of data collection, we focused on Romany localities in Brno, Ostrava and Vsetín. The overall average age is 11.9 years (11.6 boys, $12.2 \mathrm{girls}$ ). On average they were 10.5 (boys) and 12.2 (girls) years old.

\section{Results}

When summarizing the content of the utterances, a category analysis was carried out. The responses were classified in 15 categories (see the following text). Such classification made it possible to determine the amount of respondents who scored in the given category (absolutely and proportionally in the total number of respondents in the sample). We could also determine the amount of category units - i. e. the number of the same responses, e.g. in the category animal, out of the maximum amount of answers - and their percentage in the maximum possible amount of category units (category units = individual responses classified in categories.) The maximum number of category units for each subject was twelve (nine sentences and three wishes). The categories were translated to the Czech language by Válková (1996) and used in another research (Válková, 1998, 2000) among pupils, students and adults visiting the same type of the school such as the pupils of the Romany ethnic minority group. According to our findings, the categories are suitable for our target group but we added the category distaste for school and gave the category hurting of oneself or another person instead of food. We realized minimum differences in comparison with the original (Válková, 2000) - for example, we added physical in sport activities, because not all the answers were in relation to elite sport.

An overview of the research findings can be found in Table 1. For better arrangement, we also present the results in a chart. The respondents in the age group between 9 and 13 years regard the following categories as most important: performance orientation (17.98\%); common activities are on the second position (15.71\%); things is also noticeable (13.69\%); ideals (11.79\%); however, physical activity also plays an important role in their lives (10,83\%). The subjects put almost no emphasis on categories related to distaste for school $(0.35 \%)$, weather $(0.48 \%)$, hurting of oneself or another person $(0.71 \%)$ and animals (0.83\%). 
Table 1

The scale of subjective preferences to personal values in Romany pupils

\begin{tabular}{|c|l|c|c|c|c|}
\hline $\mathrm{n}=70$ & & subjects & $\%$ & categories & $\%$ \\
\hline 1 & Animals & 6 & 8.57 & 7 & 0.83 \\
\hline 2 & Hurting & 4 & 5.71 & 6 & 0.71 \\
\hline 3 & Common activities & 58 & 82.86 & 132 & 15.71 \\
\hline 4 & Performance orientation & 60 & 85.71 & 151 & 17.98 \\
\hline 5 & Things & 48 & 68.57 & 115 & 13.69 \\
\hline 6 & Home & 45 & 64.29 & 82 & 9.76 \\
\hline 7 & Weather & 4 & 5.71 & 4 & 0.48 \\
\hline $\mathbf{8}$ & Hypercriticism & 37 & 52.86 & 47 & 5.6 \\
\hline $\mathbf{9}$ & Indiscrimination & 32 & 45.71 & 45 & 5.36 \\
\hline 10 & Behavior & 14 & 20 & 16 & 1.90 \\
\hline 11 & Physical activities & 42 & 60 & 91 & 10.83 \\
\hline 12 & Ideals & 40 & 57.14 & 99 & 11.79 \\
\hline 13 & Abstract contents & 28 & 40 & 32 & 3.81 \\
\hline 14 & I don't know & 7 & 10 & 11 & 1.30 \\
\hline 15 & Distaste for school & 3 & 4.29 & 3 & 0.36 \\
\hline
\end{tabular}

Subject - number of persons replayed the content category

Subject \% - percentage of those persons

Categories - frequency of categorical units in determined content category

Categories \% - percentage of these units

With respect to the variation of the findings among Romany boys and girls the most significant difference seems to be in the category of material preference for things (boys $17.1 \%$, girls $9.64 \%)$. Similarly distinct is also the difference in stressing the importance of physical activity (boys $14.47 \%$, girls $6.51 \%$ ). Ideals in life are emphasized especially by girls (14.58\%) when compared to boys (9.43\%). Several indicators showed very similar results for both boys and girls (focus on performance - $17.32 \%, 18.75 \%$; uncriticalness $5.04 \%, 5.73 \%$; behavior $-1.97 \%, 1.82 \%)$. 
Table 2

The scale of subjective preferences of Romany pupils - boys

\begin{tabular}{|c|c|c|c|c|c|}
\hline $\mathrm{n}=38$ & & subjects & $\%$ & categories & $\%$ \\
\hline 1 & Animals & 1 & 2.63 & 2 & 0.43 \\
\hline 2 & Hurting & 1 & 2.63 & 3 & 0.66 \\
\hline 3 & Common activities & 32 & 84.21 & 67 & 14.69 \\
\hline 4 & Performance orientation & 34 & 89.47 & 79 & 17.32 \\
\hline 5 & Things & 28 & 73.68 & 78 & 17.10 \\
\hline 6 & Home & 24 & 63.16 & 38 & 8.33 \\
\hline 7 & Weather & 3 & 7.89 & 3 & 0.65 \\
\hline 8 & Hypercriticism & 18 & 47.36 & 20 & 4.38 \\
\hline 9 & Indiscrimination & 17 & 44.73 & 23 & 5.04 \\
\hline 10 & Behavior & 9 & 23.68 & 9 & 1.97 \\
\hline 11 & Physical activities & 28 & 73.68 & 66 & 14.47 \\
\hline 12 & Ideals & 19 & 50 & 43 & 9.43 \\
\hline 13 & Abstract contents & 20 & 52.53 & 21 & 4.61 \\
\hline 14 & I don't know & 2 & 5.26 & 3 & 0.70 \\
\hline 15 & Distaste for school & 1 & 2.63 & 1 & 0.22 \\
\hline
\end{tabular}

Subject - number of persons replayed the content category

Subject \% - percentage of those persons

Categories - frequency of categorical units in determined content category

Categories \% - percentage of these units 
Table 3

The scale of subjective preferences of Romany pupils - girls

\begin{tabular}{|c|l|c|c|c|c|}
\hline $\mathrm{n}=32$ & & subjects & $\%$ & categories & $\%$ \\
\hline 1 & Animals & 5 & 15.62 & 5 & 1.3 \\
\hline 2 & Hurting & 3 & 9.36 & 3 & 0.78 \\
\hline 3 & Common activities & 26 & 81.25 & 65 & 16.93 \\
\hline 4 & Performance orientation & 26 & 81.25 & 72 & 18.75 \\
\hline 5 & Things & 20 & 62.5 & 37 & 9.64 \\
\hline 6 & Home & 21 & 65.63 & 44 & 11.46 \\
\hline 7 & Weather & 1 & 3.13 & 1 & 0.26 \\
\hline $\mathbf{8}$ & Hypercriticism & 19 & 59.38 & 27 & 7.03 \\
\hline $\mathbf{9}$ & Indiscrimination & 15 & 46.88 & 22 & 5.73 \\
\hline 10 & Behavior & 5 & 15,63 & 7 & 1,82 \\
\hline 11 & Physical activites & 14 & 43.75 & 25 & 6.51 \\
\hline 12 & Ideals & 21 & 65.63 & 56 & 14.58 \\
\hline 13 & Abstract contents & 8 & 25 & 11 & 2.86 \\
\hline 14 & I don't know & 5 & 15.62 & 8 & 2.09 \\
\hline 15 & Distaste for school & 2 & 6.25 & 2 & 0.52 \\
\hline
\end{tabular}

Subject - number of persons replayed the content category

Subject \% - percentage of those persons

Categories - frequency of categorical units in determined content category

Categories \% - percentage of these units 
Chart 1

Preference of physical activities and performance orientation

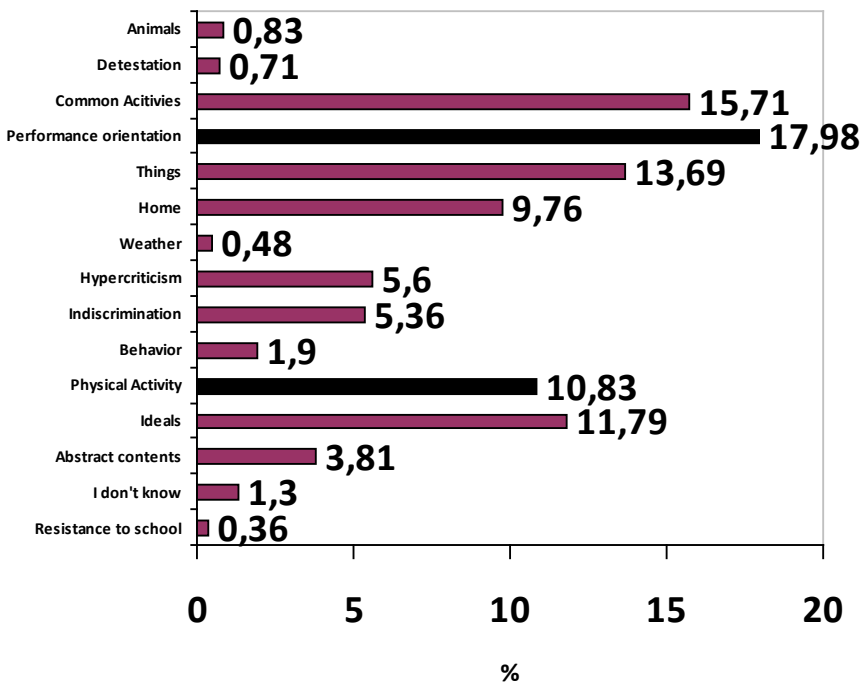

$\mathrm{x}$ - percentage of categorical units in determined content category

$y$-categories

Unlike the performance orientation, however, the focus on physical activities is markedly different for boys and girls of the Romany ethnicity. The girls do not regard physical activity as an important life preference as the boys do.

\section{Chart 2}

Categories of physical activity and performance orientation
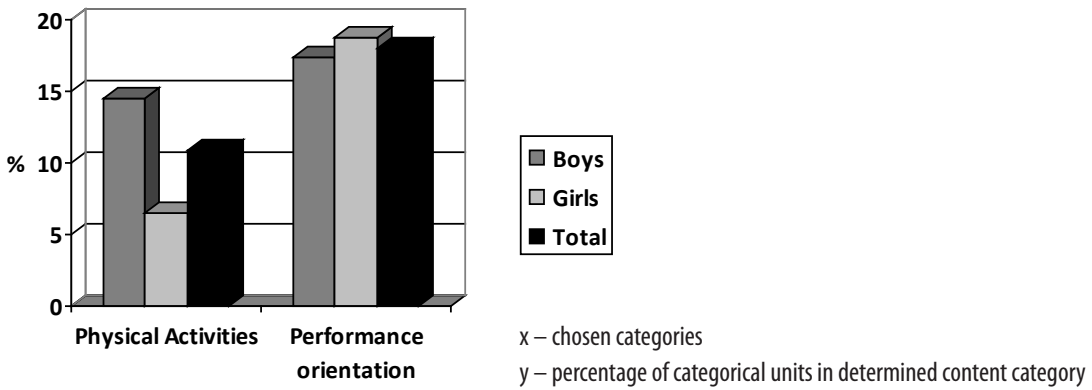
The development of the focus on physical activity and performance is depicted in Chart 3. Both indicators play an important role in the general subjective preferences of the Romany pupils between 9 and 13 years of age. Especially for boys, these preferences are stabilizing once they come to the second year at the elementary school. The interest of girls in physical activity as such is on the other hand gradually declining. Because of a small number of respondents, we cannot generalize the results.

\section{Chart 3}

Focus on physical activity and performance orientation in different ages

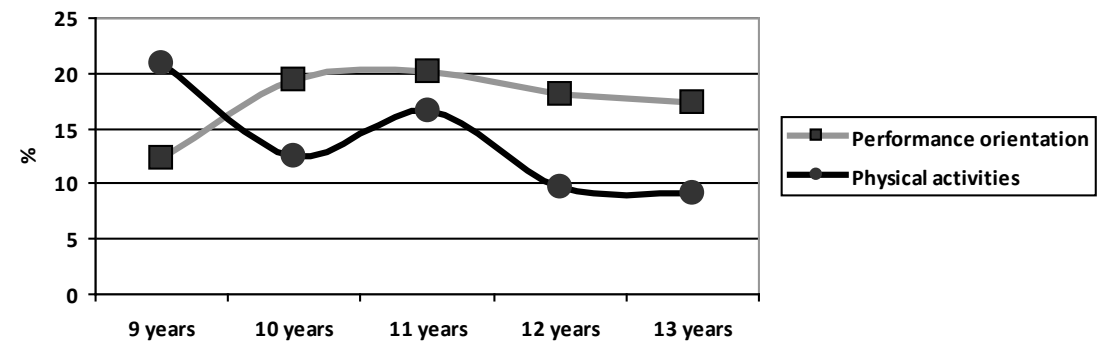

\subsection{Discussion}

Subjective preferences for physical activities could be one of the key prerequisites for the Romany pupils to actually participate in sport activities. Unlike the opinion of some other authors (Horváthová, 2002), our findings did not confirm greater preferences on spirituality rather than material things. Focus on things (meaning material sources) reached the third top position in the order of preferences. In compliance with Nečas (2002), we can conclude that in the area of material orientation the historical identity described by numerous other authors (Daniel 1994; Fraser, 1995; Jánský, 1995) was lost.

With respect to the preferences, the focus on performance orientation is the most important subjective preference for the Romany pupils. This confirms the general situation in the society that univocally requires performance orientation from people. However, Romany pupils often direct this focus to things that are not acceptable by the majority society. Frequently, the performance does not relate to e. g. knowledge at school but rather to the activities improving one's position in the social group. This finding is in contradiction with e. g. Ševčíková (2003) who stated that there is a general lack of interest in one's career among Romany people. The results of our study suggest that such indifference correlates with the value orientation only of girls but not boys.

What was also interesting were the results related to ideals that especially for girls play a very important role. Our findings show that as the children are getting older their 
emphasis on ideals is even greater. Such a tendency indicates a certain type of escape into the realm of spirituality that however does not correspond with any decreasing importance of the material world. The results rather suggest that there is a maximalistic effort to gain something in both of these areas.

Also their awareness of a need of home is increasing with the age of the respondents. This tendency is connected with the growing awareness of the security provided at home (also in the sense of a community). Furthermore, we found only a minimal emphasis on behavior, hurting of oneself or another person, distaste for school, and surprisingly (taking into account the historical context) also on animals. These points have permanent changes of the Romany people's social environment in the Czech Republic.

Physical activity has a relatively significant role in the value orientation of the Romany pupils. We did not find any marked decline of interest in sport activities as the age of the respondents increased. Moreover, interesting, although not surprising, is the finding related to the Romany girls who do not emphasize physical activities (including dancing) as much as it might be expected. Unlike the girls, however, the boys evaluate sport activities as the fourth most important value, right after the common activities.

\section{Conclusion}

Our research shows the focus on performance is even more stable than the focus on physical activity. When reaching the second year at the elementary school the focus on performance is stable especially for boys. On the other hand girls lose their interest in physical activities. Although it is empirically well known, we did not expect such a marked difference between boys and girls.

Based on the results of the study we can answer the postulated research questions.

1. What is the structure of subjective preferences to personal values in the studied Romany pupils?

Our findings show that the most important preference seems to be the performance orientation (17.98\%), common activities (15.71\%), focus on things (13.69\%), ideals (11.79\%) and physical activities (10.83\%).

2. What are the differences between the subjective preferences to personal values between the boys and the girls?

We discovered significant differences especially in the focus on things (boys $17.1 \%$, girls $9.64 \%$ ). Also, the difference in stressing physical activity is quite significant (boys $14.47 \%$, girls $6.51 \%$ ). Ideals are emphasized mainly by the girls $(14.58 \%$ ) in comparison to the boys (9.43\%).

3. What is the position of physical activity and performance orientation within the general subjective preferences of the Romany boys and girls? 
According to our findings, physical activity and especially focus on performance play a very important role in the subjective preferences of the Romany pupils aged 9 to 13 years. Mainly thanks to the boys' preferences, physical activity reached the fourth position, and focus on performance is for both sexes even the most significant preference.

If physical activities have a positive influence on the personality of the person in the age of adolescence then it is necessary to promote the participation of pupils of the Romany ethnicity. Due to the specific wishes of these pupils, it is necessary to find the preferred physical activities that appropriately shaped his personality. Physical activities realised by the Roma population of pupils should serve as a tool for overall development of personality in its psycho-social integrity. The emphasis is not possible only on performance but, on the contrary, performance should be used as a motivational element for maintaining in the physical programmes. Only under these circumstances it can be used as material orientation on (things) and gradually change external motivation into interior motivation, which lasts longer and is even better due to the positive effect of motional activities.It is possible to use the motivational elements associated with the ideals of beauty, nice-figure games "on something" for girls. These physical activities, most of the game with a story, can act as an incentive to them and allow you to keep the girls in the physical activities longer.

Although the physical activities for older pupils lose its position they still play a major role in their preferences. Suitably chosen intervention programs then open the possibility to transfer the trained models behavior with games and sports activities into real life. Organised physical activities enable you to develop certain skills that are relevant for life today - overcoming obstacles, respect for opponents or teammates, digestion of victory and failures, to allow pupils to be leaders, the response of the around help to real self-evaluation, compliance with the rules and the general rules of the group, humility, certification authorities, team spirit, identification with the group, etc.

\section{Acknowledgement}

The report was written with the support by the project of Centrum podpory integrace, CZ.1.07/1.2.00/08.0117, supported by the European Social Fund the and Czech national budget. 


\section{References}

Bakaláŕ, P. (2004). Psychologie Romů. Praha: Votobia Praha.

Balvín, J. (2004). Výchova a vzdělávání romských žáků jako pedagogický systém. Praha: Radix Hnutí R.

Baranowski, T., Bouchard, C., Bar-Or, O. et al. (1994). Assessment, Prevalence, and Cardiovascular Benefits of Physical Activity and Fitness in Youth. Medicine \& Science in Sports \& Exercise, 24(6), 237-47.

Block, M. (2007). A Teacher's Guide to Including Student with Disabilities in General Physical Education (3rd ed.). Maryland: Paul H. Brooks Publishing Co.

Boyce, B. A. (1996). Dealing with Student Diversity through the Case Study Approach. Journal of Physical Education, Recreation and Dance, 67(5), 46-50.

Butt, K. L., \& Pahnos, M. L. (1995). Why We Need a Multicultural Focus in Our Schools. Journal of Physical Education, Recreation and Dance, 66(1), 48-53.

Daniel, B. (1994). Dějiny Romů: vybrané kapitoly z dějin Romů v západní Evropě, v Českých zemích a na Slovensku. Olomouc: Univerzita Palackého.

Fraser, A. (1995). The Gypsies. Oxford: Blackwell.

Freedson, P. S. (1991). Electronic Motion Sensors and Heart Rate as Measures of Physical Activity in Children. Journal of School Health, 61(5), 220-223.

Gabal analysis and consulting (2006). Analýza sociálně vyloučených romských lokalit a absorpční kapacity subjektů působících v této oblasti. Praha: MPSV.

Harrison, L., \& Worthy, T. (2001). „Just like All the Rest“: Developing Awareness of Stereotypical Thinking in Physical Education. Journal of Physical Education, Recreation and Dance, 72(9), 20-24.

Hodge, S. R. (1997). Mentoring: Perspectives of Physical Education Graduate Students from Diverse Cultural Backgrounds. Physical Educator, 54(4), 181-195.

Horňák, L. (2005). Rómský žiak ve škole. Prešov: Horovská univerzita v Prešově.

Horváthová, J. (2002). Kapitoly z dějin Romů. Praha: Člověk v tísni, společnosti při ČT, o. p. s.

Hutchinson, G. E. (1995). Gender-fair Teaching in Physical Education. Journal of Physical Education, Recreationa and Dance, 66(1), 42-47.

Chepyator-Thomson, J. (1994). Multicultural Education. Culturally Responsive Teaching. Journal of Physical Education, Recreation and Dance, 65(9), 31-32.

Jánsky, P. (1995). Je problém Romů neřešitelný? Speciální pedagogika, 5(4), 13-16.

Jesenský, J. (1995). Kontrapunkty integrace zdravotně postižených. Praha: Karolinum.

Ješina, O., Kudláček, M., et al. (2011). Aplikovaná tělesná výchova. Olomouc: UP.

Kahan, D. (2003). Islam and Physical Activity: Implications for American Sport and Physical Educators. Journal of Physical Education, Recreation and Dance, 74(3), 48-54.

King, S. E. (1994). Winning the Race against Racism. Journal of Physical Education, Recreation and Dance, 65(9), 69-74.

Kudláček, M., \& Ješina, O. (2008). Integrace žáků s tělesným postižením do školní tělesné výchovy. Olomouc: Univerzita Palackého.

McCollum, S., Civalier, A., \& Holt, A. (2004). Equitable Learning for Spanish Speaking Students in Elementary Physical Education. Strategies, 17(6), 21-23.

Nečas, C. (2002). Romové v České republice včera a dnes. Olomouc: Univerzita Palackého.

Pate, R. R., Trost, S. G., Felton, G. M. et al. (1997). Correlates of Physical Activity Behaviour in Rural Youth. Research Quarterly for Exercise and Sport, 68(3), 241-248.

Rybová, L., \& Kudláček, M. (in press). Integrace žáků s tělesným postižením v hodinách školní tělesné výchovy. Studia sportiva.

Říčan, P. (1998). S Romy žít budeme - jde o to jak. Praha: Portál. 
Sallis, J. F., \& Patrick K. (1994). Physical Activity Guidelines for Adolescents: Consensus Statement. Pediatric Exercise Science, 6, 302-314.

Sallis, J. F., Patterson, T. L., Buono, M. J. et al. (1988). Aggregation of Physical Activity Habits in Mexican-American and Anglo families. Journal Behavioral Medicine, 11(1), 31-41.

Sallis, J. F., Prochaska, J. J., \& Taylor, W. C. (2000). A Review of Correlates of Physical Activity of Children and Adolescents. Medicine \& Science in Sports \& Exercise, 32(5), 963-975.

Sekyt, V. (1998). Odlišnosti mentality Romů a původ těchto odlišností. In T. Šisková (Ed.), Výchova $k$ toleranci a proti rasismu. Praha: Portál.

Sparks, W. G. III. (1994). Culturally Responsive Pedagogy: A Framework for Addressing Multicultural Issues. Journal of Physical Education, Recreation and Dance, 65(9), 33-36, 61.

Sutherland, S. L., \& Hodge, S. R. (2001). Inclusion of a Diverse Population. Teaching Elementary Physical Education, 12(2), 18-21.

Sutliff, M. (1996). Multicultural Education for Native American Students in Physical Education. The Physical Educator, 53, 157-163.

Sutliff, M., \& Perry, J. (2000). Multiculturalism: Developing Connections in Elementary Physical Education. Strategies, 13(5), 33-36.

Ševčíková, V. (2003). Sociokulturní a hudebně výchovná specifika romské minority v kontextu doby. Ostrava: Ostravská univerzita.

Šotolová, E. (2001). Vzdělávání Romů. Praha: Grada.

Trost, S. G., Pate, R. R., Saunders, R. et al. (1997). A Prospective Study of the Determinants of Physical Activity in Rural Fifth Grade Children. Preventive Medicine, 26, 257-263.

Válková, H. (2000). Skutečnost nebo fikce? Socializace mentálně postižených prostřednictvím pohybových aktivit. Olomouc: Univerzita Palackého.

Válková, H. (1998). The Development of Indices of Motor Competence and Social Behavior of Participants and Non-participants in the Special Olympics Movement. Acta Universitatis Palackianae Olomucensis, 28, 53-60.

Válková, H. (1996). The Differences in Behaviour Indices of Participants and Non-participants in Special Olympics Movement. Acta Universitatis Palackianae Olomucensis gymnica, 26, 39-46.

Vítková, M. (2006). Somatopedické aspekty. Brno: Paido.

Wessinger, N. P. (1994). Celebrating Our Differences: Fostering Ethnicity in Homogenous Settings. Journal of Physical Education, Recreation and Dance, 65(9), 62-68.

Žáková, H. (1976). Některé poznatky z výzkumu sociální adaptace a přičin psychické retardace cikánských dětí. In Výchova a vzdèlávání cikánských dětí - sborník přednášek (pp. 29-43). Ústí nad Labem: Ústav školských informací při Ministerstvu školství ČSR.

\section{Contact:}

Mgr. Ondřej Ješina, Ph.D.

Mgr. Tomáš Vyhlídal

Department of Adapted Physical Activity

Faculty of Physical Culture

Palacký University in Olomouc

tř. Míru 111, 77111 Olomouc 